\title{
THE INFLUENCE OF BOARD INDEPENDENCE AND INTERNAL AUDIT FUNCTION ON COMPANY'S PERFORMANCE, STUDY OF MACEDONIAN COMPANIES
}

\author{
Elena Bundaleska ${ }^{1}$ \\ Aleksandra Kocheska ${ }^{2}$ \\ Vladimir Naumovski ${ }^{3}$
}

Received: May 6, 2020 / Revised: June 3, 2020 / Accepted: June 12, 2020

(C) Association of Economists and Managers of the Balkans, 2020

\begin{abstract}
Corporate governance and company performance are issues that continue to raise interests of the researchers worldwide, as they provide valuable lessons for vast audience, such as company owners, company leaders, supervisors and policy makers. This study aims towards contributing to the previous literature showing that there is positive correlation between corporate governance mechanisms and company performance. It specifically focuses on the correlation between board independence and internal audit function existence with performance of the companies listed on the Macedonian Stock Exchange, for specific periods 2003-2004 vs. 20142018. In particular, the influence of the board independence and the internal audit function over company performance are investigated through Profit, Return on Equity (ROE) and Earnings per Share (EPS) indicators. The results of the performed research and analysis suggest that corporate governance is important for the company performance, i.e. corporate governance improvements such as board member independence and internal audit function have positive impact on the performance of the companies listed on the Macedonian Stock Exchange. However, given the fact that, other factors apart from board member independence and internal audit function can influence the Profit, ROE and EPS of companies, it is reasonable to assume that the increase of profit and of ROE and EPS indicators may not be connected exclusively with having independent board members and internal audit function. First and foremost, this study is of interest for company owners and leaders; yet, it also provides useful information for supervisors and other policy makers.
\end{abstract}

Keywords: Corporate governance, Company performance, Independent board members, Internal audit function, Listed companies.

\section{JEL Classification G34}

bundaleska@uacs.edu.mk

University American College Skopje, Treta Makedonska Brigada No. 60, 1000 Skopje. North Macedonia University American College Skopje, Treta Makedonska Brigada No. 60, 1000 Skopje. North Macedonia Commission for Protection of Competition, Kiril and Methodij No. 54 (6th floor), 1000 Skopje, North Macedonia 


\section{INTRODUCTION}

Corporate governance is a never ending process that continuously evolves. It is not a final destination at which a company can arrive and stay for an extended period of time. Since it includes "procedures and processes according to which an organization is directed and controlled" (European Central Bank, 2004), these procedures and processes need to be updated and enhanced continuously, in order to give best possible results. In the past 20 years, many of the high-profile corporate collapses (such as Enron Corp. in 2001, WorldCom Inc. in 2002, Lehman Brothers in 2007/8, British Petroleum in 2010, Volkswagen AG in 2015, Toshiba in 2015, etc.) were linked to non-existent, or inefficient and/or ineffective corporate governance systems. According to many studies, the implementation and compliance with sound corporate governance practices improves and leads to company's better performance (Apostolov, 2011; Velnampy, 2013; Christensen, Kent, Routledge \& Stewart, 2015).

Building upon these studies, this paper shall further investigate whether the independence of the board members and existence of internal audit function have influence on the performance of the Macedonian companies. It shall assess the performance of the Macedonian companies listed on the Macedonian Stock Exchange (super listing and regular listing), for the years 2003 and 2004, as period prior to the adoption of the current Company Law of $2004^{4}$ and the years 2014, 2015, 2016, 2017 and 2018, as a post adoption of the Law period. It shall accordingly make conclusions based on the results of the conducted research.

\section{LITERATURE REVIEW}

The research related to corporate governance and its effects on company performance has increased significantly throughout the years. This chapter reviews literature highlighting corporate governance developments, especially in the area of the relationship between board independence, internal audit and company performance.

\subsection{Review of definitions for corporate governance}

There are usually different views of the nature and the essence of corporate governance, which is mostly due to the variety of different approaches taken by different scholars and practitioners, and the complexity of the issue. The most widely used definition of corporate governance is that corporate governance is "a system by which companies are directed and controlled" (Cadbury, 1992, p. 15). More specifically it is the framework by which various stakeholder interests are balanced. It requires a "set of relationships between company's management, its board, its shareholders and other stakeholders", contributing towards a "structure through which the objectives of a company are set, and the means of attaining those objectives and monitoring performance are determined" (OECD, 2004).

\subsection{Corporate Governance and Company Performance}

Different studies have investigated the benefits of sound corporate governance practices on company performance. Ho $(2005$, p. 1) states that "corporate governance attributes are inter-related", therefore assessment of corporate governance based on one attribute may not explain the overall corporate governance effect on company performance. In addition, Bauer, Frijns, Otten \& Tourani-Rad (2008) find that "not all categories affect corporate performance", thus improvement

$4 \quad$ Including the changes of the Company Law related to the internal audit function, applicable since 2011 
of only one particular element of corporate governance might not lead to better performance. Research done by Cheung, Evans and Nagarajan (2008) reveals that the corporate governance attributes are working simultaneously, meaning that in some cases they may substitute for each other, while in other cases they may be complementary. Further on, in their study, Vo and Nguyen (2014, p.11) propose solutions for companies to "enhance firm performance through improving corporate governance". All these studies show to some extent that there is a correlation between corporate governance and company performance.

On the other hand, there are empirical studies, most of them not so recent, that have not found a statistically significant positive relationship between corporate governance improvements and improved company performance (Bhagat \& Black, 2002; Ramadan El-Faitouri, 2014; Baysinger \& Butler, 1985; Hermalin \& Weisbach, 1991).

\subsection{Independence of the Board and Company Performance}

The board of directors has been recognized as an important corporate governance mechanism and in light with all the corporate scandals that happened throughout the years more and more regulation was aimed towards improving the structure and the independence of the boards (Sarbanes Oxley Act of 2002 in US, EU 8th Company Law Directive, etc.)

According to the Macedonian Company Law of 2004, the independence of board members is measured through:

- not having any material interest or business relation with the company directly as a business partner, a member of the management body, supervisory body or an officer of;

- not receiving from the company additional income, again within the previous 5 (five) years,

- not being a relative of any of the members of the management body, supervisory board or the officers of the company; and

- not bring a shareholder with more than $1 / 10$ of the shares in the company.

Many researchers have proven that board independence is important not only for the companies, but for the overall economy. For example, Collier (2006) argues that strengthening board independence and other company-level mechanisms of corporate governance could improve the weakness of the companies, thus attract foreign investment, and consequently have significant positive influence on the economy.

Typical one tier board of directors consists of two types of directors, executive and non-executive. Mostly, the non-executive directors are seen as "significant long-term and impartial decision-makers and overseers of the governance process" (Higgs, 2003, p. 93). Hence, outside independent board members are perceived as directors that take a "fresh, objective look at business challenges and opportunities, and offer advice that synthesizes the perspectives of all parties while enabling the company to pursue short- and long-term business objectives" (Eimer, 2008).

The past literature shows inconclusive at times and historically mixed findings regarding the relation between board independence and company performance. Namely, some studies have found an insignificant relationship between the presence of outside independent directors and company financial performance (Hermalin \& Weisbach, 1991; Bhagat \& Black, 2000; Klein, 2002; Garg, 2007), while other studies have shown that there is a positive relationship between board independence and firm performance (Abdullah, 2004; Ameer, Ramli \& Zakaria, 2010; Leung, Richardson \& Jaggi, 2013). 


\subsection{Internal Audit Function and Company Performance}

The Internal Audit Function is one of the most important functions when it comes to enhanced corporate governance and sound running of a company. Organizing an internal audit function is crucial, as it is a unit that keeps track and oversees the operations of all the units in a company. Management of a company that is striving to protect the interests of all the stakeholders should make sure that the company has "independent, objective" (Pickett, 1976) strong and influential internal audit function.

Generally, previous literature dedicated to examining the relationship between internal audit and company performance is limited. Past studies were mostly focused on the relationship of the external audit or characteristics of an audit committee and company performance (Hassan \& Farouk, 2014; Kipkoech \& Rono, 2016; Zraiq \& Fadzil, 2018). There are some, but not many, studies that focus on characteristics of the internal audit function and company performance (Hutchinson \& Zain, 2009; Al-Matari, Al-Swidi \& Fadzil, 2014).

This study explores if the mere existence of internal audit function, in combination with other corporate governance improvements, such as board independence, can influence company performance.

\section{HYPOTHESIS AND METHODOLOGY}

The hypothesis of the research is:

Hypothesis: Corporate governance improvements such as board independence and internal audit function have positive impact on the performance of the Macedonian companies.

Below, the methods used to test the hypothesis are presented.

\subsection{Type of data, research approach and methods of data collection}

This study considers the effect of certain corporate governance improvements on the performance of the Macedonian companies, by extracting data from annual reports of all the companies on the super and regular listing on the Macedonian Stock Exchange. In order to confirm the hypothesis and to meet the research objectives, both secondary and primary data were used, for the documentary and empirical investigation respectively.

The periods that were researched are the years 2003 and 2004, as period prior to the adoption of the current Company Law of $2004^{5}$ (including the changes of the Law related to the internal audit function, applicable since 2011) and the years 2014, 2015, 2016, 2017 and 2018 as a post adoption of the Law period.

During the periods stated above (2003-2004 and 2014, 2015, 2016, 2017 and 2018) 66 companies in total were regularly or from time to time, listed on super and regular listing on the Macedonian Stock Exchange. Only certain number of those companies was chosen for future analysis in this paper because of data availability for the referred periods. The companies included in the research were: Alkaloid Skopje, Beton Skopje, Granit Skopje, Fersped Skopje, DS Smith AD Skopje, Hoteli Metropol Ohrid, Makpetrol Skopje, Makedonijaturist Skopje, Replek Skopje, RZ Inter-transsped Skopje, RZ Uslugi Skopje, Skopski Pazar Skopje, Makstil Skopje, Teteks Tetovo, Tutunski

Prior to 2004 there was no legal requirement to have independent members on the boards. 
kombinat Prilep, Vinarska vizba Tikves Skopje, Toplifikacija Skopje, Vitaminka Prilep, Zito luks Skopje, ZK Pelagonija Bitola and Makosped Skopje. Banks were not part of the research due to different regulations and corporate governance standards.

The performance indicators used were Profit, Return on Equity (ROE) and Earnings per Share (EPS), obtained mostly from annual reports of the stated companies.

The study used descriptive and comparative analysis to assess and analyze the collected data.

\subsection{Correlation}

The purpose of the correlation is to determine whether there is a quantitative agreement between the variations of the observed phenomena (correlation link) and if there is a degree or intensity (Damghani, 2013). If two phenomena are observed, there is a simple correlation, and in the analysis of multiple phenomena there are multiple correlations. In a simple correlation it is possible to examine whether there are linear or curvilinear correlations between the phenomena.

\section{RESULTS AND ANALYSIS}

This study initially started to analyze 21 companies (twenty one companies continuously quoted from 2003 to 2018 on super listing and regular listing) in terms of Profit, ROE, EPS, number of independent directors and existence or not of internal audit function (for 2014, 2015, 2016, 2017, 2018), for the years 2003 and 2004 versus 2014, 2015, 2016, 2017 and 2018.

The calculations below were made on the one tier and two-tier management systems, since 11 companies had two-tier and 10 companies had one tier management system. Considering the fact that the independence of the members in this paper was majorly mentioned as independence of the board of director's members, which is a board common for the one-tier management system, it is necessary to clarify that the independence requirement in the two-tier management system refers to independence of the Supervisory Board members.

Analysis of the correlation between the change of the number of independent members on one side and the increase/decrease of the Profit, ROE, EPS indicators, by years, on the other side, was made. Comparing the years 2003-2004 with the years 2014-2018, most of the companies in 20032004, except for 6 companies, did not have independent members in their boards, while stating from 2014 all the companies have independent members in their boards.

As for the internal audit function, analysis of the available data showed that since 2011 all of the listed companies had internal audit functions, since it was a legal requirement starting from the same year.

On the other hand, the growth rates for the stated periods of the Profit, ROE and EPS are inconsistent.

\subsection{First Analysis}

In the period 2003-2018, for six companies the number of independent members did not change, meaning that these companies had independent member/s throughout the entire period. They had interdependent members even in the years 2003-2004, when most of the other analyzed companies did 
not have independent members, due to the fact that there was no legal requirement to have such members. These 6 companies thought, could not be analyzed in terms of board independence influence on Profit, ROE and EPS, since they continuously had the same number of independent members.

Therefore, the final analysis was made on 15 companies that had changes in the variables, which could be used for the purpose of the analysis. These companies are:

Beton, Granit, Hoteli Makpetrol the number of the independent members has increased from 0 to 1 in 2004-2014, and the profit has increased as well. The increase happened in ROE and EPS (except in Granit's EPS which was decreased). Therefore, positive correlation was found.

Fersped, DS Smith, RZ Uslugi, Skopski Pazar, ZK Pelagonija, Makosped, the number of the independent members has increased from 0 to 1 in 2004-2014, but the profit has decreased. The decrease happened with the ROE and EPS as well (except in Skopski Pazar`s EPS and Makosped 's ROE which were increased instead of decreased). Therefore, negative correlation was found in these cases.

Replek and Tutunski Kombinat Prilep, the number of the independent members has increased from 0 to 2 in 2004-2014, and the profit (the loss in Tutunski Kombinat was decreased) has increased as well. The increase happened in ROE and EPS (except in Tutunski kombinat where ROE and EPS were decreased). Therefore, positive correlation was found.

RZ Inter-Transsped and Teteks, the number of the independent members has increased from 0 to 2 in 2004-2014, but the profit has decreased. The decrease happened with the ROE and EPS as well. Therefore, negative correlation was found.

Makedonijaturist, the number of the independent members has increased from 0 to 3 in 2004-2014, and the profit has increased as well. The increase happened in EPS and ROE. Positive correlation was found.

Vinarska Vizba Tikves (which was one of the six companies that had independent members in the board even in 2003-2004), the number of the independent members has decreased from three to one in 2004-2014, but the profit has increased. The increase happened in ROE, but not in EPS. Therefore, negative correlation was found.

\subsection{Second Analysis}

Second analysis was made on the correlation coefficient between the total number of independent members in all the companies and the profit of all the companies, by years. The value of the coefficient is 0.47 (see Table 1 below), which means that there is positive correlation found.

Table 1. Correlation

\begin{tabular}{|l|c|c|c|c|c|c|c|}
\cline { 2 - 8 } \multicolumn{1}{c|}{} & \multicolumn{7}{c|}{ Years } \\
\hline Coefficient of correlation & $\mathbf{2 0 0 3}$ & $\mathbf{2 0 0 4}$ & $\mathbf{2 0 1 4}$ & $\mathbf{2 0 1 5}$ & $\mathbf{2 0 1 6}$ & $\mathbf{2 0 1 7}$ & $\mathbf{2 0 1 8}$ \\
\hline $\begin{array}{l}\text { Total number of independent } \\
\text { directors }\end{array}$ & 11 & 11 & 30 & 30 & 29 & 28 & 28 \\
\hline Total profit of all companies & 515.429 & 811.287 & 509.011 & 1.418 .591 & 1.164 .183 & 1.217 .989 & 2.211 .309 \\
\hline $\begin{array}{l}\text { Total Coefficient of correlation } \\
\text { for all companies and years }\end{array}$ & \multicolumn{7}{|c|}{$\mathbf{0 , 4 7 5 4 3 3 1 3 8}$} \\
\hline
\end{tabular}

Note: Coefficient of correlation could not be calculated for individual companies annually, neither periodically, due to the statistically insignificant number of independent members. 


\section{LIMITATIONS AND FUTURE STUDIES}

The study has limitations that could be addressed in future research, such as:

\section{- Data availability and verification limitations}

From the beginning of the research, the collection of the necessary data was challenging due to various reasons. Referring to the annual reports on the operation of the companies and the financial statements of the companies listed in 2003 and 2004, parts of the reports could not be found, since in accordance with the rules applicable at that period, not all companies were required to disclose the analyzed information, and not all data was kept in electronic form. Trying to overcome this obstacle, part of the information was collected from proxy statements, official company websites, the website of the Macedonian Securities Exchange Commission (seinet.com.mk), and direct communication with authorized persons in the companies. For the 21 selected companies, most of the data was gathered, with minor exception of several companies. For the period 2014, 2015, 2016, 2017 and 2018 the data was gathered more easily, since with the adoption of the Corporate Governance Code in 2006, the companies listed on the Macedonian Stock Exchange were required to disclose financial and other company data relevant for this research.

When trying to analyze the ROE and EPS data, gathering the data for the period 2003-2004 was challenging, since out of 21 analyzed companies, all of the companies had disclosed data about ROE, for all the relevant years, while most of the companies had not disclosed EPS data for the period 2003-2004.

Lastly, given the history of accounting scandals, limitation such as manipulation of financial statements should also be mentioned, even though most of the financial statements were audited.

- Limitations in terms of correlation between the given indicators and the company performance

Other factors, apart from independence of the board members and existence of internal audit function may influence company performance. Other industry and company specific or presumably institutional and market parameters may affect the results. Future studies may include more variables than the given ones.

\section{- Limitations in terms of limited number of analyzed companies in the study}

The analysis was made on companies listed on the Macedonian Stock Exchange since these are the companies that had most of the disclosure and transparency requirements, given the fact that the Macedonian companies in comparison with international companies have a lot to learn about disclosing information to the public. Therefore, studies with larger and random samples of companies from different countries may be conducted in the future.

\section{- Cultural limitations}

The study could not determine whether the independence of the board members and the existence of the internal audit function were actually mechanisms used by the companies in practice or only on paper. This means that, the study covered all the companies that 
had independent board members and internal audit functions without having information on whether these two corporate governance improvements existed in these companies in reality or the companies had them just to satisfy legal requirements, without actually using these benefits in practice.

\section{CONCLUSION}

This study aims towards contributing to the previous literature showing that there is positive correlation between corporate governance mechanisms and company performance. It specifically focuses on the correlation of the independent board members and internal audit function and company performance of the companies listed on the Macedonian Stock Exchange, for specific periods 2003-2004 vs. 2014-2018.

Concisely, this study finds that as the numbers of independent board members is increasing, and the internal audit function is introduced as mandatory function, the selected indicators of company performance in majority of the cases increase as well, thus leading to positive correlation.

Consequently, this study concludes that, corporate governance improvements such as board member independence and internal audit function have positive impact on the performance of the Macedonian companies.

\section{REFERENCES}

Abdullah, S. (2004). Board composition, CEO duality and performance among Malaysian listed companies. Corporate Governance, 4(4), 47-61. https://doi.org/10.1108/14720700410558871

Al-Matari, E. M., Al-Swidi, A. K., \& Fadzil, F. H. (2014). The Measurements of Firm Performance's Dimensions. Asian Journal of Finance \& Accounting, 6(1), 24-49. https://doi. org/10.5296/ajfa.v6i1.4761

Al-Saidi, M., \& Al-Shammari, B. (2015). Ownership concentration, ownership composition and the performance of the Kuwaiti listed non-financial firms. International Journal of Commerce and Management, 25(1), 108-132. https://doi.org/10.1108/ijcoma-07-2013-0065

Ameer, R., Ramli, F., \& Zakaria, H. (2010). A new perspective on board composition and firm performance in an emerging market. Corporate Governance: The International Journal of Business in Society, 10(5), 647-661. https://doi.org/10.1108/14720701011085607

Apostolov, M. (2011). Corporate governance in Macedonia - Micro and macro analysis. Risk Governance and Control - Financial Markets and Institutions, 1(1), 124-134.

Bauer, R., Frijns, B., Otten, R., \& Tourani-Rad, A. (2008). The impact of corporate governance on corporate performance: Evidence from Japan. Pacific-Basin Finance Journal, 16(3), 236251. https://doi.org/10.1016/j.pacfin.2007.05.001

Baysinger, B. D., \& Butler, H.N. (1985). Corporate governance and the board of directors: Performance effects of changes in board composition. Journal of Law, Economics, \& Organization, 1(1), 101-124.

Bhagat, S. \& Black, B. (2002). The Non-correlation between board independence and long-term firm performance. Journal of Corporation Law, 27, 231-273. Review of Quantitative Finance and Accounting, 31(2), 461.

Christensen, J., Kent, P., Routledge, J., \& Stewart, J. (2015) Do corporate governance recommendations improve the performance and accountability of small listed companies? Journal Accounting \& Finance, 55(1), 133-164. 
Coles, J., \& Hesterly, W. (2000). Independence of the chairman and board composition: Firm choices and shareholder value. Journal of Management, 26(2), 195-214. https://doi. org/10.1177/014920630002600202

Committee on the Financial Aspects of Corporate Governance., \& Cadbury, A. (1992). Report of the Committee on the Financial Aspects of Corporate Governance. London: Gee.

Damghani, B. M. (2013). The non-misleading value of inferred correlation: An introduction to the Cointelation Model. Wilmott, 2013(67), 50-61. https://doi.org/10.1002/wilm.10252

El-Faitouri, R. (2014). Board of directors and Tobin's Q: Evidence from U.K. firms. Journal of Finance and Accounting, 2(4), 82-99. https://doi.org/10.12691/jfa-2-4-2

Eimer, J. (2008). Is electing an independent board member right for your business? Exploring the pros and cons. Retrieved from https:/www.muchlaw.com/insights/article/electing-independent-board-member-right-your-business-exploring-pros-and-cons

European Central Bank. (2004). Annual Report: 2004. Retrieved from https://www.ecb.europa. eu/pub/pdf/annrep/ar2004en.pdf

Garg, A. K. (2007). Influence of board size and independence on firm performance: A study of Indian companies. Vikalpa: The Journal for Decision Makers, 32(3), 39-60. https://doi. org/10.1177/0256090920070304

Hassan, S. U. \& Farouk, M. A. (2014). Board of director's characteristics and performance of listed deposit money banks in Nigeria. Journal of Finance and Bank Management, 2(1), 89-105.

Hassan, R., Marimuthu, M., \& Johl, S. (2015). Ethnic diversity on boards and market performance: An empirical investigation in Malaysia. Advanced Science Letters, 21(5), 10991103. https://doi.org/10.1166/asl.2015.6036

Hermalin, B., \& Weisbach, M. (1991). The effects of board composition and direct incentives on firm performance. Financial Management, 20, 101-112.

Higgs, D. (2003). Review of the role and effectiveness of non-executive directors. [PDF file]

Ho, C. (2005). Corporate governance and corporate competitiveness: An international analysis. Corporate Governance: An International Review, 13(2), 211-253. https://doi.org/10.1111/ j.1467-8683.2005.00419.x

Hutchinson, M., \& Zain, M. (2009). Internal audit quality, audit committee independence, growth opportunities and firm performance. Modern Pathology, 7(2), 50-65. https://doi. org/10.22495/cocv7i2p4

Klein, A. (2002). Audit committee, board of director characteristics, and earnings management. Journal of Accounting and Economics, 33(3), 375-400. https://doi.org/10.1016/S01654101(02)00059-9

Kipkoech, S. R., \& Rono, L. (2016). Audit committee size, experience and firm financial performance. Evidence Nairobi Securities Exchange, Kenya. Research Journal of Finance and Accounting, 7(15), 87-95. https://www.iiste.org/Journals/index.php/RJFA/article/view/32732.

Leung, S., Richardson, G., \& Jaggi, B. (2014). Corporate board and board committee independence, firm performance, and family ownership concentration: An analysis based on Hong Kong firms. Journal of Contemporary Accounting \& Economics, 10(1), 16-31. https://doi. org/10.1016/j.jcae.2013.11.002

Organization for Economic Co-operation and Development. (2004). OECD Principles of corporate governance. Paris: OECD.

Pickett, S. (1976). The internal audit handbook. Retrieved from https://www.academia. edu/11623270/Audit_Internal-Picket_and_Spencer_Internal_Auditing

Shukeri, S. N., Shin, O. W., \& Shaari, M. S. (2012). Does board of director's characteristics affect firm performance? Evidence from Malaysian public listed companies. International Business Research, 5(9). https://doi.org/10.5539/ibr.v5n9p120 
Tachiwou, A. M. (2016). Corporate governance and firms' financial performance of listed company in the West African Monetary Union (Wamu) regional financial exchange. International Journal of Economics and Finance, 8(8), 212. https://doi.org/10.5539/ijef.v8n8p212

Tehrani, N. (2019). Investigating the effects of corporate governance system quality on company performance. International Academic Journal of Accounting and Financial Management, 06(01), 56-65.

Velnampy, T. (2013). Corporate governance and firm performance: A study of Sri Lankan manufacturing companies. Journal of Economics and Sustainable Development, 4(3), 228-235.

Vo, D., \& Nguyen, T. (2014). The impact of corporate governance on firm performance: Empirical study in Vietnam. International Journal of Economics and Finance, 6(6), 11. https://doi. org/10.5539/ijef.v6n6p1

Zraiq, M.A.A., \& Fadzil, H.B.F. (2018). The impact of ownership structure on firm performance: Evidence from Jordan. International Journal of Accounting, Finance and Risk Management, 3(1), 1-4. https://doi.org/10.11648/j.ijafrm.20180301.12 